\title{
Heavy Mineral Compositions of Sediments in the Southern Okinawa Trough and Their Provenance-Tracing Implication
}

\author{
Bowen Zhu ${ }^{1,2,3,4}$ and Zhigang Zeng ${ }^{1,2,3,4, *}$ \\ 1 CAS Key Laboratory of Marine Geology and Environment, Institute of Oceanology, Chinese Academy of \\ Sciences, Qingdao 266071, China; zhubowen@qdio.ac.cn \\ 2 Laboratory for Marine Mineral Resources, Qingdao Pilot National Laboratory for Marine Science and \\ Technology, Qingdao 266061, China \\ 3 Center for Ocean Mega-Science, Chinese Academy of Sciences, Qingdao 266071, China \\ 4 University of Chinese Academy of Sciences, Beijing 100049, China \\ * Correspondence: zgzeng@qdio.ac.cn
}

Citation: Zhu, B.; Zeng, Z. Heavy Mineral Compositions of Sediments in the Southern Okinawa Trough and Their Provenance-Tracing Implication. Minerals 2021, 11, 1191. https:// doi.org/10.3390/min11111191

Academic Editors:

David Gómez-Gras and Marta Roigé

Received: 11 September 2021

Accepted: 18 October 2021

Published: 27 October 2021

Publisher's Note: MDPI stays neutral with regard to jurisdictional claims in published maps and institutional affiliations.

Copyright: (c) 2021 by the authors. Licensee MDPI, Basel, Switzerland. This article is an open access article distributed under the terms and conditions of the Creative Commons Attribution (CC BY) license (https:// creativecommons.org/licenses/by/ $4.0 /)$.

\begin{abstract}
Heavy mineral assemblages have been widely used to effectively trace sediment sources. Heavy mineral assemblages are rarely used in research to trace sediment sources in the southern Okinawa Trough compared with geochemical proxies. In this study, the TESCAN Integrated Mineral Analyzer (TIMA) revealed the full-size heavy mineral assemblages in the five layers of the core sediment H4-S2 in the southern Okinawa Trough. During the past 700 years, the heavy mineral assemblages in the sediments of the southern Okinawa Trough were very similar to the East China Sea shelf/Yangtze River, mainly composed of mica and chlorite; dolomite; actinolite; and hematite/magnetite. The grain size distribution of heavy minerals is in the clay-sand range and mainly in silt. Actinolite and hornblende can indicate the supply of sediments from the East China Sea shelf/Yangtze River to the southern Okinawa Trough. Due to their complex sources, pyrite, epidote, and hematite/magnetite are not adequate indicators for distinguishing between the different provenance areas. Because previous studies have used a variety of analytical methods, especially using heavy liquids with different densities, dolomite cannot be used as a marker for sediments on the Yangtze River/East China Sea shelf. Therefore, the East China Sea shelf/Yangtze River is a vital provenance of sediments from the southern Okinawa Trough since the late Holocene period.
\end{abstract}

Keywords: heavy minerals; sediment provenance; Okinawa Trough; the East China Sea shelf

\section{Introduction}

The southern Okinawa Trough (SOT), as the deepest region of the Okinawa Trough (OT), has the highest deposition rate of the Holocene, about $9.5 \mathrm{~m} / \mathrm{ka}$ [1]. Due to its extremely fast deposition rate, the SOT has become a key area for the study of oceanic circulation and paleoclimate evolution [2]. Thus, the provenance of the SOT is in the spotlight. Despite extensive research, studies on the source of sediments in the SOT since the Holocene have been inconclusive [2]. The Sr-Nd isotopic composition indicates the provenance of SOT sediments since the Holocene in Taiwan rivers [3,4]. However, the $\mathrm{Sr}-\mathrm{Pb}$ isotopic composition of the surface sediments in the SOT indicates a mixture of about $60 \%$ from Taiwan rivers, 30\% of Chinese Loess, and 10\% from the Yangtze River [5]. Other proxies, for instance, rare earth elements (REEs) characteristic of bulk sediments, indicate a mixture of sediments from the Yangtze River and Taiwan rivers since $3.0 \mathrm{ka}$ [6]; The total organic carbon (TOC) and total nitrogen (TN) of the surface sediments are similar to those of the East China Sea shelf [7]. Meanwhile, smectite has appeared in the SOT since the Holocene [2], but this mineral is not present in Taiwan river sediments [8], indicating that smectite-rich provenance areas, such as the East China Sea, and the Yangtze River have a significant sediment supply to the SOT [2]. Therefore, the Yangtze River, the East China 
Sea shelf, and Taiwan rivers should be the potential provenance areas of sediments in the SOT since the Holocene.

Although sedimentary processes such as hydrodynamic sorting and mechanical destruction during transport and weathering can fractionate heavy mineral assemblages, they have long been used as effective proxies of sediment provenance $[9,10]$. Several heavy mineral studies have been carried out on potential provenance areas for the SOT [11-15]. However, in the past, a specific size of 63-125 $\mu \mathrm{m}$ was often selected for heavy mineral analysis, thereby reducing the particle size effect or the impact of hydrodynamic separation [16,17], and then reflecting as much as possible the mineral composition of the river into the sea and the nature of the bearing rock $[13,15]$. However, previous studies reported that the equivalent sedimentation effect might lead to significant differences in the composition of heavy minerals with different grain sizes in the same sample. The narrower the grain size range, the more significant the difference in the composition may be [9]. Meanwhile, it was considered that the heavy minerals with a higher specific gravity are relatively enriched in the fine-grained components [18]. Thus, if $63-125 \mu \mathrm{m}$ is selected, the content of heavy minerals in the range $<63 \mu \mathrm{m}$ will be significantly underestimated. Therefore, by expanding the particle size range to conduct a more comprehensive analysis of the composition of heavy minerals, it is possible to eliminate the deviation of the mineral composition caused by the difference in the particle size selection [19]. In the southern Okinawa Trough, unlike the extensive application of geochemical and clay mineral indicators, few studies have focused on the provenance significance of heavy minerals. Furthermore, there have not been any reports on the assemblages of full-size, fraction heavy minerals in this region.

In this study, we report the full-size fraction heavy mineral assemblages from H4-S2, aiming to (1) reveal the heavy mineral assemblages characteristics of sediments in the SOT since the late Holocene; (2) to determine the provenance of sediments in the SOT since the late Holocene; (3) to propose a mineral index for a provenance analysis to distinguish the sediments from the Yangtze River, the East China Sea shelf, and Taiwan rivers; (4) to explore the applicability of TESCAN Integrated Mineral Analyzer (TIMA) method to the study of heavy mineral assemblages of marine sediments.

\section{Materials and Methods}

\subsection{Materials and Age Model}

The sediment core H4-S2 ( $477 \mathrm{~cm}$ in length, $\left.122^{\circ} 37^{\prime} 19.702^{\prime \prime} \mathrm{E}, 24^{\circ} 52^{\prime} 49.906^{\prime \prime} \mathrm{N}\right)$ was located on the SOT (Figure 1) with a water depth of $1505 \mathrm{~m}$. This study focused on heavy mineral assemblages from five layers of H4-S2 $(26-66 \mathrm{~cm}, 112-152 \mathrm{~cm}, 192-232 \mathrm{~cm}$, $332-372 \mathrm{~cm}$, and $402-442 \mathrm{~cm}$ ). The age model was constructed on the basis data of the accelerator mass spectrometry (AMS) ${ }^{14} \mathrm{C}$ dating of planktonic foraminifera picked from 6 layers (Figure 2). The depositional age at $477 \mathrm{~cm}$ was 624a BP [20], with a sedimentation rate of $0.69 \mathrm{~cm} / \mathrm{yr}$. The depositional ages of five samples were established by the Bacon software package (version 2.3.9.1) (Table 1) [21].

Table 1. The depth, deposition ages, and heavy mineral grains of five layers in H4-S2.

\begin{tabular}{cccc}
\hline Sample & Depth $(\mathbf{c m})$ & Deposition Ages (cal. yr AD) & Heavy Mineral Grains \\
\hline OTS-1 & $26-66$ & $1954-1993$ & 97 \\
OTS-2 & $112-152$ & $1828-1879$ & 425 \\
OTS-3 & $192-232$ & $1748-1793$ & 634 \\
OTS-4 & $332-372$ & $1580-1641$ & 240 \\
OTS-5 & $402-442$ & $1536-1544$ & 720 \\
\hline
\end{tabular}



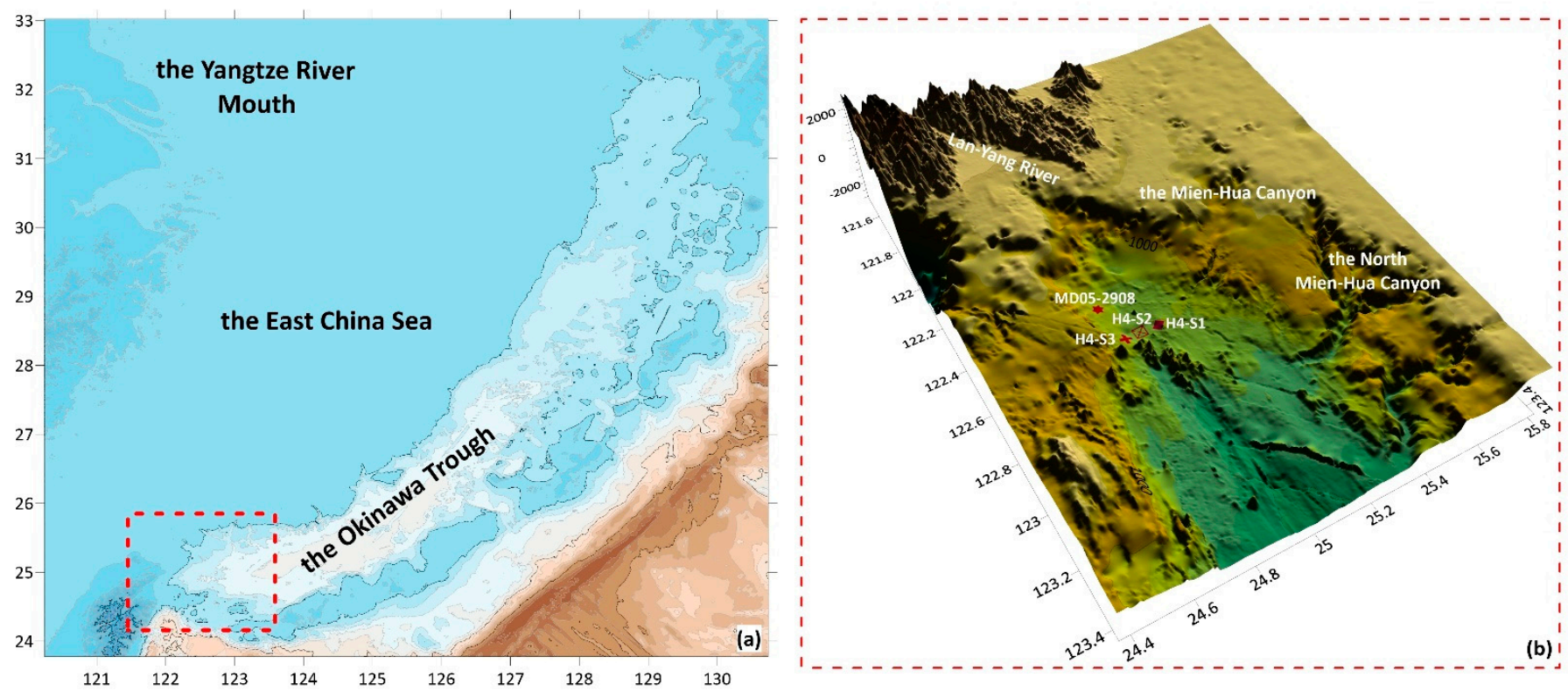

Figure 1. Map of the study area showing the location of H4-S2 and other cores (a,b); Topographic data comes from https:/ / www.gebco.net/ (accessed on 7 August 2021). The specific location of this research is within the red dotted line.

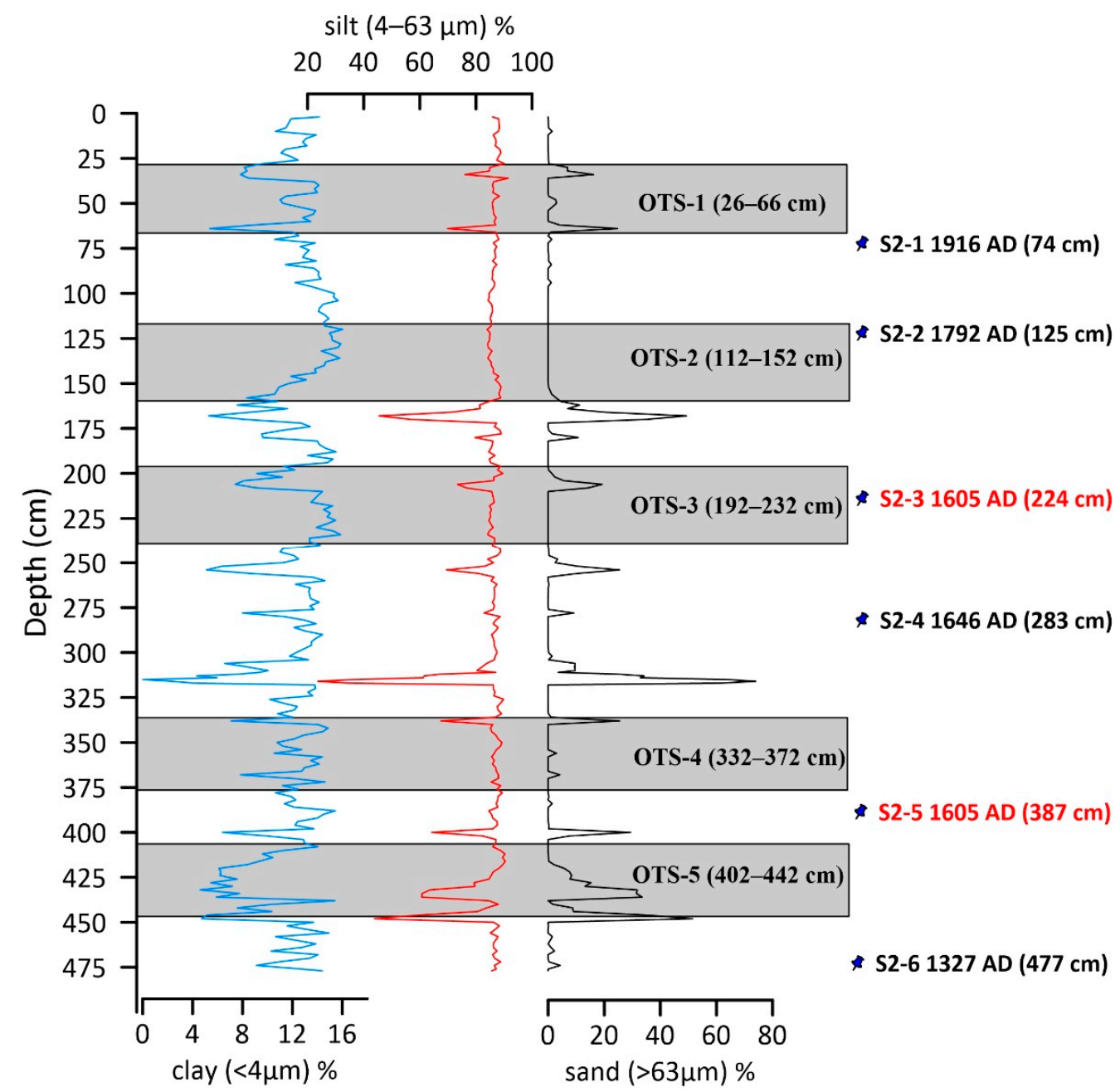

Figure 2. Location diagram of heavy mineral assemblage samples. Grain size composition is quoted from reference [20]. Sampling locations are marked by gray rectangles. 


\subsection{Heavy Mineral Analysis}

More than $400 \mathrm{~g}$ of bulk sediments were obtained for each sample. After sufficient mixing, $10 \mathrm{~g}$ of each sample was selected for heavy mineral analysis. Samples were separated using the standard procedure of heavy liquids. The density of the heavy liquid used was $2.80 \mathrm{~g} / \mathrm{cm}^{3}$ and was obtained by diluting the standard heavy liquid with a density of $2.89 \mathrm{~g} / \mathrm{cm}^{3}$. For dilution method, refer to reference [15].

We randomly sprinkled and mounted heavy mineral grains in epoxy resin. Then, we used a modern automated mineralogical approach (TESCAN Integrated Mineral Analyzer, TIMA, Beijing, China) that was adopted for detailed (either complex or selective) insights into the phase/mineral and grain size distribution. The test of TIMA was carried out in Nanjing Hong Chuang Geological Exploration Technology Service Co., LTD. using a Mira-3 scanning electron microscope equipped with four energy dispersive spectrometers (EDAX Element 30). The samples were sprayed with carbon before the experiment. In the experiment, the acceleration voltage was $25 \mathrm{kV}$, the current was $9 \mathrm{nA}$, and the working distance was $15 \mathrm{~mm}$. The current and backscattered electron (BSE) signal strengths were calibrated by the platinum Faraday cup automatic program, and the energy dispersive spectrometer (EDS) signal was calibrated by Mn standard sample. The liberation analysis mode was used in the test, and both BSE and EDS data were obtained, with an X-ray count of 1000 for each point. The pixel size was $1 \mu \mathrm{m}$, and the energy spectrum step was $3 \mu \mathrm{m}$.

\section{Results}

\subsection{Heavy Mineral Assemblages}

A total of 32 heavy mineral species were identified, including 19 species of content in more than $1 \%$, dominated by mica and chlorite, dolomite, actinolite, and followed by epidote, hornblende, hematite/magnetite, and $\mathrm{TiO}_{2}$ polymorphs, then zircon, titanite, schorl, ilmenite, olivine, andradite, and apatite. Other identified heavy minerals include pyrite, pyrrhotite, annite, tremolite, monazite, baryte, $\mathrm{Al}_{2} \mathrm{SiO}_{5}$ polymorphs, galena, anhydrite, alunite, and chalcopyrite. (Table 2).

In OTS-1, the heavy mineral assemblages are dominated by actinolite (18.57\%), epidote $(18.56 \%)$, and mica and chlorite $(11.34 \%)$. In OTS-2, the heavy minerals are mainly composed of dolomite $(29.18 \%)$, mica and chlorite $(25.88 \%)$, and actinolite $(10.35 \%)$. In OTS-3, the heavy mineral composition is characterized by high contents of mica and chlorite (34.54\%), dolomite (27.76\%), and actinolite (10.09\%). In OTS-4, the heavy mineral assemblages are dominated by mica and chlorite $(27.08 \%)$, dolomite $(16.67 \%)$, and actinolite (14.58\%). In OTS-5, the heavy minerals are mainly composed of mica and chlorite (24.31\%), dolomite (17.78\%), and actinolite (14.58\%).

\subsection{Grain Size of Major Heavy Mineral Phases}

In addition to the relative content of various heavy minerals, this study also obtained the grain size distribution of the heavy mineral particles through TIMA. Among them, the size range of mica and chlorite was $2.20-172.00 \mu \mathrm{m}$ and most of the particles $(72-82 \%)$ were distributed in the range of silt $(4-63 \mu \mathrm{m})$; the size range of actinolite was $2.20-111.00 \mu \mathrm{m}$ and most of the particles were silt (76-83\%); the particle size range of hornblende was $2.20-131.00 \mu \mathrm{m}$ and $77-86 \%$ of the particles were silt; and the particle size range of epidote was $2.20-111.00 \mu \mathrm{m}$ with a higher silt content (83-96\%). Among the major heavy minerals, dolomite had the finest particles $(2.20-75.00 \mu \mathrm{m})$. Eight-five to ninety-six percent of the particles were in the range of silt (Figure 3). Therefore, if a particle size range of 63-125 $\mu \mathrm{m}$ was used for heavy mineral analysis, most of the information about the composition of heavy minerals is lost. 

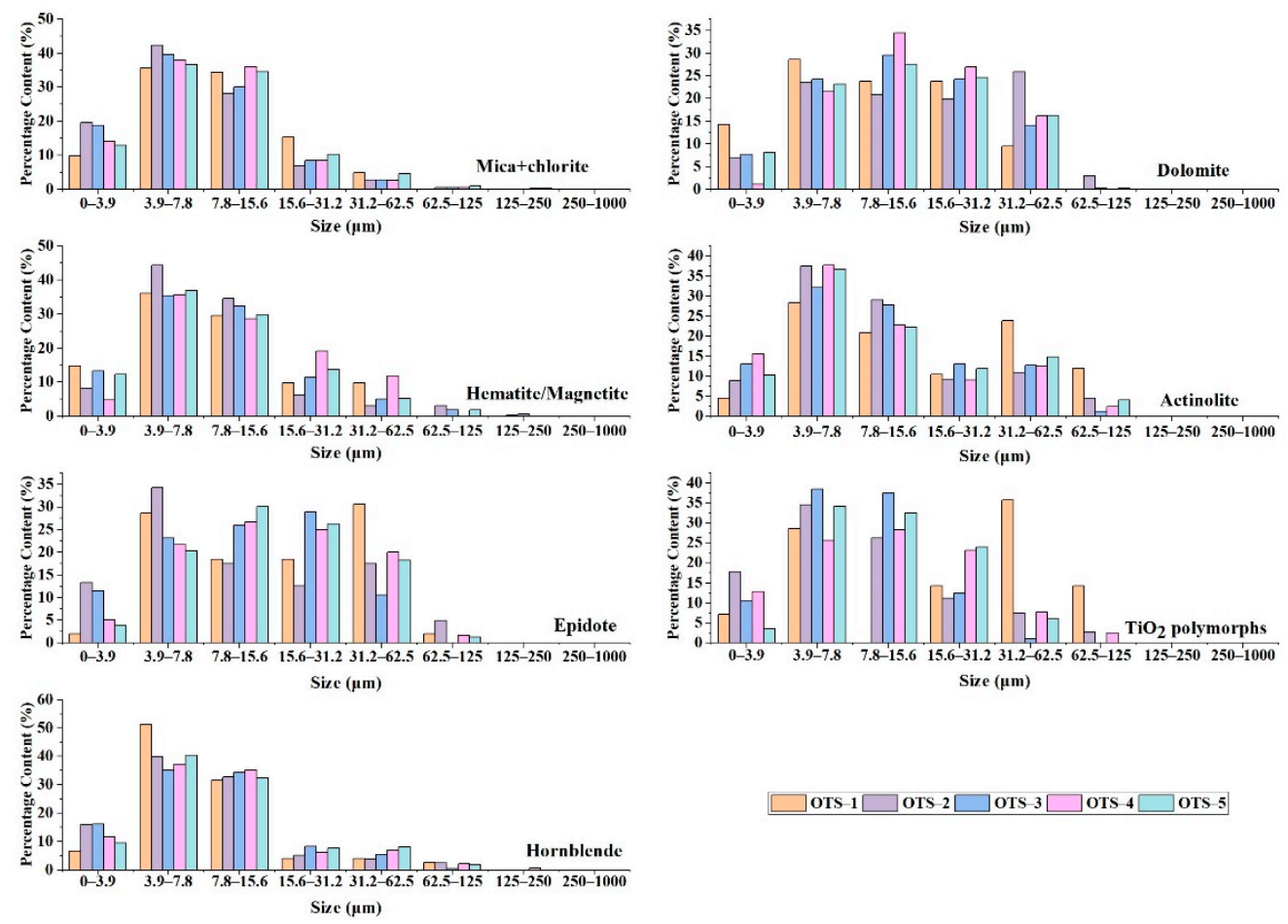

$\square$ OTs $1 \square$ OTs $-2 \square$ OTS $-3 \square$ OTS $4 \square$ OTS 5

Figure 3. Histogram of grain size distribution of main heavy mineral phases from H4-S2.

\subsection{Heavy Mineral Assemblages in the Potential Provenance Area}

In order to understand the difference between the SOT and the potential provenance area, this study compiled the heavy mineral assemblage data of the Yangtze River, the East China Sea shelf, Taiwan rivers, and other SOT boreholes (Table 3). It should be noted that the studies of Taiwan rivers and H4-S3 focused on heavy mineral assemblages with a full grain size, while other regions were interested in heavy mineral assemblages in the 63-250 $\mu \mathrm{m}$ range $[6,13-15,22,23]$. Meanwhile, all of the previous studies in the potential provenance areas were conducted by traditional petrographic heavy mineral identification. Therefore, the heavy mineral assemblage in the potential source area may be different from that in this study. In particular, actinolite only appears in H4-S1 [22], which may be caused by the inability of traditional petrographic analysis to distinguish actinolite from hornblende. 
Table 2. The major heavy mineral content (>1\%) of H4-S2.

\begin{tabular}{|c|c|c|c|c|c|c|c|c|c|c|c|c|c|c|c|c|c|c|c|}
\hline Sample & $\begin{array}{c}\text { Grain Size } \\
\text { Range }\end{array}$ & Hbl & Ep & $\begin{array}{c}\mathrm{Bt}+\mathrm{Ms}+ \\
\mathrm{Chl}\end{array}$ & Dol & Act & Tur & $\begin{array}{c}\text { Iron } \\
\text { Oxides }\end{array}$ & $\mathrm{Ol}$ & $\begin{array}{c}\mathrm{Tio}_{2} \\
\text { Polymorphs }\end{array}$ & Adr & Ttn & $\mathrm{Ilm}$ & Ap & Py & Pyrrhotite & Zrn & Mnz & Brt \\
\hline OTS-1 & Whole & 4.12 & 18.56 & 11.34 & 6.19 & 18.56 & 2.06 & 11.34 & 2.06 & 7.22 & 1.03 & 3.09 & 4.12 & 4.12 & 0.00 & 1.03 & 2.06 & 2.06 & 1.03 \\
\hline OTS-2 & Whole & 4.47 & 8.00 & 25.88 & 29.18 & 10.35 & 1.18 & 5.65 & 1.88 & 3.06 & 0.47 & 1.88 & 1.18 & 2.35 & 1.65 & 0.00 & 0.47 & 0.24 & 0.24 \\
\hline OTS-4 & Whole & 5.83 & 9.17 & 27.08 & 16.67 & 14.58 & 2.92 & 5.84 & 1.25 & 3.33 & 1.67 & 2.50 & 2.08 & 3.33 & 0.83 & 0.42 & 1.67 & 0.00 & 0.00 \\
\hline OTS-5 & Whole & 4.03 & 13.61 & 24.31 & 17.78 & 14.58 & 2.08 & 7.50 & 2.64 & 3.06 & 0.56 & 2.22 & 1.67 & 3.06 & 0.28 & 0.00 & 1.39 & 0.28 & 0.00 \\
\hline
\end{tabular}

Table 3. Heavy mineral assemblages in the potential provenance area of the southern Okinawa Trough.

\begin{tabular}{|c|c|c|c|c|c|c|c|c|c|c|c|c|c|c|c|c|c|}
\hline Location & Method & $\begin{array}{l}\text { Grain Size } \\
\text { Range }\end{array}$ & $\mathrm{Hbl}$ & Ep & $\mathbf{B t}+\mathrm{Ms}+\mathrm{Chl}$ & Dol & Act & Tur & Iron Oxides & O1 & $\begin{array}{c}\mathrm{TiO}_{2} \\
\text { Polymorphs }\end{array}$ & Grt & Ttn & $\mathrm{Ilm}$ & Ap & Py & Zrn \\
\hline $\begin{array}{c}\text { The East China Sea } \\
\text { shelf }[13,23]\end{array}$ & petrographic & $63-250 \mu \mathrm{m}$ & 44.80 & 11.30 & 6.80 & 8.40 & - & - & 0.60 & 0.00 & - & 0.40 & 0.2 & - & - & - & - \\
\hline The Yangtze River [15] & petrographic & $63-250 \mu \mathrm{m}$ & 24.2 & 8.0 & 28.00 & 26.00 & - & - & 0.40 & 0.0 & - & 1.0 & 0.5 & - & - & - & - \\
\hline Lanyang river [14] & petrographic & Whole & 0.00 & 0.00 & - & - & - & - & 9.40 & - & 3.2 & 0.00 & - & 0.00 & 0.00 & 32.7 & 21.5 \\
\hline Zhuoshui river [14] & petrographic & Whole & 0.10 & 0.50 & - & - & - & 2.30 & 19.30 & - & 3.2 & 14.00 & - & 3.80 & 1.40 & 0.9 & 32.1 \\
\hline H4-S3 (SOT) [6] & petrographic & Whole & 19.08 & 33.50 & - & - & - & 1.17 & 9.57 & - & 0.43 & 1.20 & - & 7.94 & 1.39 & 2.91 & 2.67 \\
\hline H4-S1 (SOT) [22] & petrographic & $63-250 \mu \mathrm{m}$ & 47.10 & 4.40 & - & - & 6.90 & - & 10.2 & - & & - & - & - & - & - & - \\
\hline
\end{tabular}




\section{Discussion}

Although the East China Sea outer shelf, the Yangtze River, and the SOT have been subject to numerous studies on heavy mineral assemblages, there are many differences in the experimental methods. Excluding the difference in grain size range, a heavy liquid with a density of 2.80 was used on the Yangtze River and the East China Sea outer shelf, while the density of the heavy liquid used in the Taiwan River, H4-S3, and H4-S1 was 2.89. In addition, there have not been many TIMA methods applied in the above area. This has caused great difficulties in revealing the material contributions of different provenance areas to the SOT. Thus, in this study, the provenance significance of our results are discussed in the following sections by typical mineral, index values, and the difference between TIMA and manual identification.

\subsection{Provenance Indication of Characteristic Heavy Minerals}

Previous studies have reported differences in data selection for heavy mineral assemblages. For example, zircons from the Yangtze River, the East China Sea shelf, and H4-S1 have been identified but not included in the calculation of relative content $[13,15,22]$. At the same time, whether mica and chlorite belong to heavy minerals or light minerals has not been unified. The above difference must lead to errors in the relative contents of other heavy minerals. Therefore, the relative content of different heavy minerals is not a good indicator of the difference between H4-S2 and the potential provenance. The characteristic heavy minerals, which only exist in a specific area, may be an essential signal to determine their provenance.

Among the potential source areas of the SOT, the Yangtze River basin has a large area and complex source rocks [24], while the bedrock of Taiwan rivers consists mainly of sedimentary rock and low-grade metamorphic rock [14]. Therefore, the heavy mineral composition of these two areas is entirely different. The East China Sea shelf is an essential sink of sediments from the modern Yangtze River, the rivers entering the sea from southeastern China, and the rivers in western Taiwan [25]. At the same time, the typical residual deposits developed in the outer shelf of the East China Sea where the sediments supplied by the ancient Yangtze River were recorded during a period of low sea level [12,26]. Therefore, the types of heavy minerals in the East China Sea shelf sediments are not significantly different from those of the Yangtze River (Table 3). In general, the heavy minerals in the sediments flowing into the estuary of the Taiwan River are significantly different from those in the East China Sea shelf/Yangtze River, such as dolomite, epidote, pyrite, iron oxide, hornblende, and actinolite.

Previous studies reported that the high content of dolomite was an important feature of sediments in the Yangtze River [15]. In Taiwan rivers, magnesite is a characteristic mineral of sediments in the middle and lower reaches of Lanyang river, which originates from the dolomite in the middle reaches of the basin [14]. However, dolomite does not appear in the heavy minerals of Lanyang river, which seems to be inconsistent with the nature of the bedrock. The apparent absence of dolomite in the heavy mineral assemblage of Langyang river is likely to reflect the use of a heavy liquid with a density of $2.89 \mathrm{~g} / \mathrm{cm}^{3}$ [24], since dolomite $\left(2.84-2.86 \mathrm{~g} / \mathrm{cm}^{3}\right)$ will tend to float rather than sink in such circumstances. Therefore, although there is a high content of dolomite (6.19-29.18\%) in H4-S2 (Table 2), this may not be used to distinguish the sediment supply of the SOT from Taiwan rivers and the Yangtze River. Another mineral that cannot be used as a tracer is epidote. As a metamorphic mineral, epidote only occurs in the upper and middle reaches of Lanyang river, which is closely related to the metamorphic rocks developed in the upper reaches [14]. Although there are significant differences in the heavy mineral assemblages between the estuary and the upper reaches of Lanyang river, the length of Lanyang river is short $(73 \mathrm{~km})$, heavy precipitation frequently occurs in Taiwan, and so the instantaneous high-throughput fluid may directly bring the upstream sediments into the SOT.

It is well known that submarine hydrothermal activity is widely developed in the southern Okinawa Trough, and Yonaguni Knoll IV is the main example of the submarine 
hydrothermal system in this region [27]. Previous studies reported that the main products of the Yonaguni Knoll IV submarine hydrothermal system are galena, chalcopyrite, sphalerite, anhydrite, barite, and pyrite [27]. Although pyrite content was extremely high in the sediments of the estuary of Lanyang river [14], active submarine hydrothermal activities developed in the SOT had a significant impact the sedimentary environment, and there was a large amount of pyrite of hydrothermal origin in the surface sediments [28]. Therefore, the specific source of pyrite cannot be distinguished from mineral composition alone. Combined with the results of heavy mineral assemblages from the three SOT boreholes, the iron oxide content is generally high in the area (3.94-10.2\%). The sediments of the East China Sea shelf, Yangtze River and Taiwan rivers all contain iron oxides. Similar to pyrite, due to hydrothermal activity in the SOT, it is also challenging to indicate the specific source using iron oxides because it may be the weathering product of the hydrothermal origin of pyrite. At the same time, iron oxides are the main mineral facies of metal-bearing sediments [29] and are developed in hydrothermally altered basalt [30]. Therefore, the provenance of iron oxides is complex and varied. In this study, low concentrations of barite $(0.16-1.03 \%)$, pyrrhotite $(0.42-1.03 \%)$, galena $(0.24 \%)$, anhydrite $(0.16 \%)$ and chalcopyrite $(0.16 \%)$ were found in H4-S2. Clearly, fluvial and shelf sediments cannot provide these minerals for the SOT. Therefore, these minerals may originate from the hydrothermal system of the SOT, especially the Yonaguni Knoll IV. Although the contents of these hydrothermal minerals are low, they are still important provenance indicators.

Hornblende, as a common heavy mineral in igneous rocks, is widely found in the sediments of the Yangtze River and the East China Sea shelf but is almost completely absent in the sediments of Taiwan rivers flowing into the estuary [14]. The sediments of the SOT all contain hornblende (Tables 2 and 3), which indicates that the East China Sea shelf or the Yangtze River sediments are supplied to the area. Actinolite develops in H4-S1 and H4-S2 but does not appear in the sediments of Taiwan rivers, yet there are many high-value areas of actinolite on the East China Sea shelf [12]. This means that the East China Sea shelf is the primary source area of actinolite in the sediments of the SOT.

In summary, the high content of hornblende and actinolite in the core indicates that the East China Sea shelf or the Yangtze River had a sustained sediment supply to the SOT during the late Holocene. Due to the complexity of their sources, iron oxide, pyrite, and epidote are difficult to define their specific material source. Due to the deviation caused by the difference in the heavy liquid density, it cannot be arbitrarily considered that dolomite originates only from the Yangtze River or the East China Sea shelf. Sr-Nd isotope tracing results generally demonstrate that the source of SOT sediments since the Holocene is Taiwan rivers [2,3]. The mainstream view at this stage is very different from our heavy mineral tracing results. Nevertheless, it is undeniable that heavy minerals only occupy a small part of the sediments, and our results cannot completely deny the material contribution of Taiwan rivers. For the provenance of many cores in the SOT since Holocene, Taiwan rivers are still the main provenance area. However, the sediment supply to the SOT from the East China Sea shelf and the Yangtze River cannot be ignored. It should be emphasized that the emergence of submarine hydrothermal active products, such as chalcopyrite, galena, barite, pyrrhotite, and anhydrite, indicates that the submarine hydrothermal activity in the SOT causes a significant material supply to the sediments. The Yonaguni Knoll IV submarine hydrothermal system may be one of the provenance areas in this region.

\subsection{Heavy Mineral Index Analysis and Provenance Discrimination}

Under similar hydrodynamic conditions, the ratio of stable heavy minerals can reflect the provenance characteristics of sediments. Since the ratio between some special heavy minerals can resist changes during the sedimentation cycle, this type of index can be a good reflection of the characteristics of the source rock [31]. Among these indices, ATi $=100^{*}$ apatite $\% /($ apatite $\%$ + tourmaline $\%$ ) and ZTR = zircon $\%$ + tourmaline $\%$ + rutile $\%$ are commonly used. The ATi index is often used to indicate the degree of weathering of apatite 
in sediments. If weathering is weak, the change of the ATi index mainly reflects the change of provenance [32]. The ZTR index is mainly used to indicate the maturity and recycling degree of heavy minerals [33].

As mentioned above, due to the selection of different particle size ranges, heavy liquid density, and types of heavy minerals in each potential provenance area, the relative content of heavy minerals has no comparison and provenance significance. Therefore, in this study, the heavy mineral indices were used to distinguish mineral composition changes in different layers (Table 4).

Table 4. Heavy mineral index of H4-S2.

\begin{tabular}{cccccc}
\hline Index & OTS-1 & OTS-2 & OTS-3 & OTS-4 & OTS-5 \\
\hline ATi & $66.67 \%$ & $66.67 \%$ & $26.31 \%$ & $53.33 \%$ & $59.45 \%$ \\
ZTR & $11.34 \%$ & $4.71 \%$ & $4.73 \%$ & $7.92 \%$ & $6.53 \%$ \\
\hline
\end{tabular}

In this study, most of the apatite in BSE is euhedral and subhedral, and one apatite in OTS-3 may be a biological shell (Figure 4). This means that most apatite is detrital apatite. It should be noted that these morphologies may also be inaccurate as the epoxy resin target is polished. Nevertheless, the change of ATI in this study may reflect the change of provenance. The ATi index value of OTS-3 decreased significantly, indicating that the content of apatite decreased sharply in this layer and that the sediment source changed significantly. Previous studies revealed the multiple sources of detrital apatite in SOT sediments and reported that it was a product of the weathering of clastic rocks in the Lanyang river basin [34]. It is worth noting that apatite has a poor stability and is easily weathered under acidic surface water and weathering conditions [32,35], suggesting that the reduction in ATi may indicate that the sediments originated from areas with a higher weathering intensity, such as Taiwan. Therefore, the detrital apatite in SOT sediments may be directly derived from the eastern Chinese mainland, where igneous rocks are exposed in a large area. The sharp decrease in its relative content indicates the relative increase in the supply of SOT sediments by Taiwan rivers. At the same time, OTS- 3 contains the lowest content of actinolite in all layers $(10.09 \%$, Table 2$)$. The decrease in the content of these special heavy minerals means that the supply of the East China Sea shelf/Yangtze River to SOT sediments is relatively reduced. In other words, the sediment supply of Taiwan rivers sees a relative increase during this period. Except for OTS-3, the changes in the ATi index of other horizons were relatively stable, indicating that the apatite content did not undergo abrupt changes, which recorded that the sediment supply in the provenance area was stable.

The ZTR indexes of OTS-1, OTS-4 and OTS- 5 are higher than OTS-2 and OTS-3, indicating that the heavy minerals in these three horizons had a higher maturity, and that the sediments experienced a moderately longer transportation distance. Meanwhile, these three horizons had a moderately higher actinolite content, indicating that the East China Sea shelf or Yangtze River input more sediments into the SOT in the corresponding period. 


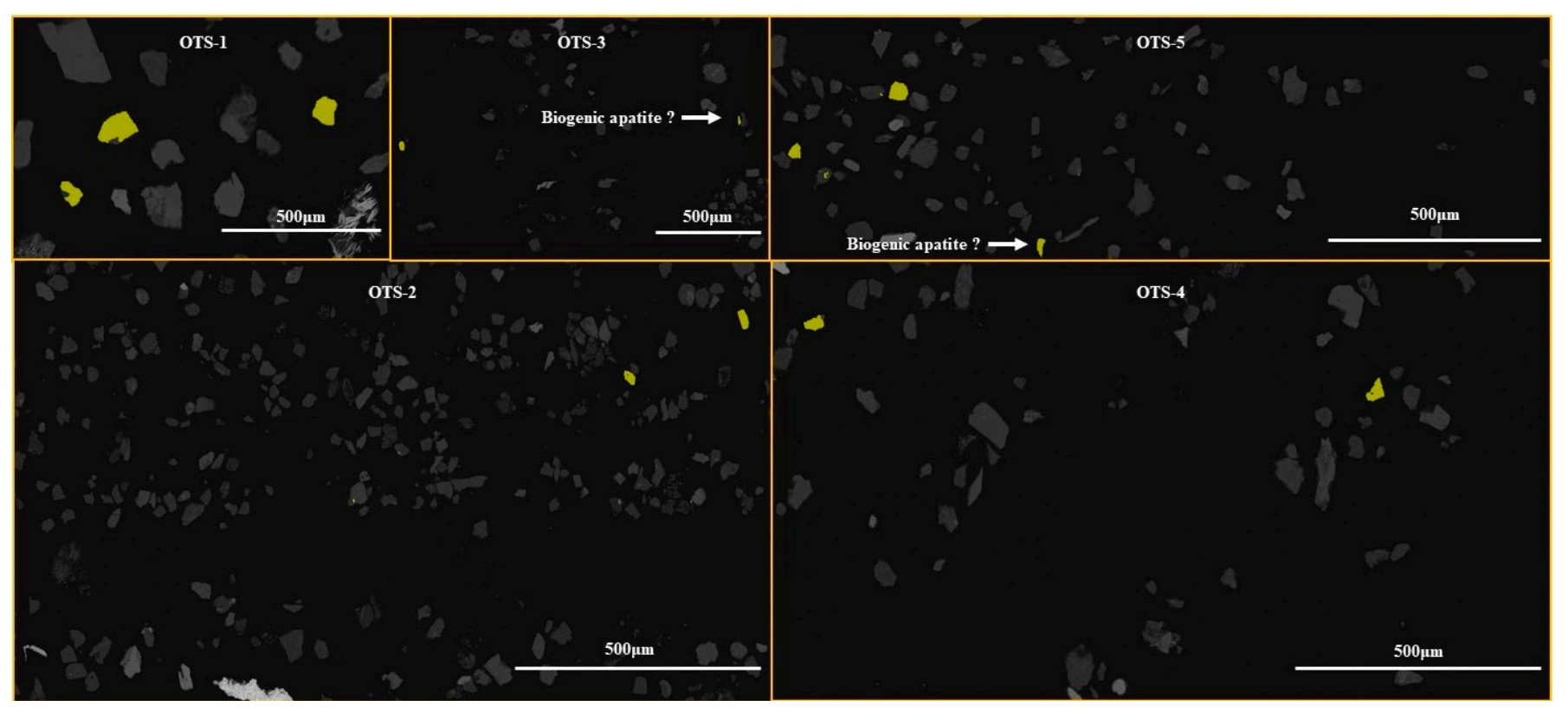

Figure 4. BSE map of apatite in H4-S2. Apatite grains were marked yellow in this map.

\subsection{Differences between TIMA and Manual Identification}

This study is the first time that the TIMA method has been applied to identify heavy minerals in the sediments of the Okinawa Trough. It should be emphasized that this study does not intend to judge the advantages and disadvantages of TIMA and manual identification. However, a recent study believes that not all operators can be capable of following the well-established methods of mineral identification [36]. This may be an important reason why the results of the manual identification were not so accurate. In the previous studies of heavy minerals in the SOT, East China Sea shelf, Taiwan rivers, and Yangtze River, some heavy mineral grains were named as rock debris and 'others' because they were difficult to identify under the microscope [12-14,22]. This result interferes with revealing the composition characteristics of heavy minerals. Although the TIMA method requires heavy minerals to be targeted and polished, a process that sacrifices the topography of the minerals, TIMA is significantly more efficient and accurate.

It should be noted that from the data obtained in this study, the TIMA method could not accurately distinguish between hematite and magnetite, as well as any minerals with heteromorphisms, such as rutile-anatase-brookite and andalusite-sillimanite-kyanite. Moreover, TIMA could not distinguish biogenic apatite from detrital apatite without the evidence of petrographic methods or BSE. At the same time, Xu et al. also reported that the TIMA method could not accurately identify minerals with similar chemical compositions that belonged to different types or minerals with heteromorphisms [37]. This kind of error caused by chemical composition should be taken seriously in future analyses. If the number of samples allows in the future, heavy mineral combination analysis, manual identification, and TIMA should be combined to eliminate the errors mentioned above.

Previous studies reported that selecting full-size heavy mineral combination analysis could effectively avoid the bias caused by hydrodynamic separation and could more comprehensively reveal provenance information $[12,18,19,37]$. TIMA is undoubtedly a necessary tool for this analysis. The grain size composition of the heavy minerals obtained in this study shows that most of the heavy minerals in the H4-S2 sediments were concentrated in the silt range (3.9-62.5 $\mu \mathrm{m})$, and this part was mostly not used in the previous manual identification. At the same time, it was difficult to obtain the grain size composition of the corresponding mineral phases by manually identifying the composition of heavy minerals in the full-size range. As we all know, the sedimentary dynamic conditions of silt particles and sand particles are entirely different, and silt particles are easier to transport over 
long distances. Therefore, the TIMA method is also helpful in revealing the depositional dynamics of heavy minerals in marginal sea sediments.

\section{Conclusions}

(1) The heavy mineral assemblages in the sediments of the southern Okinawa Trough are similar to those of the East China Sea shelf or Yangtze River. They are mainly composed of mica and chlorite, dolomite, epidote, actinolite, and hematite/magnetite, which are distinctly different from Taiwan rivers.

(2) Hornblende and actinolite are important indicators to distinguish the material supply to the southern Okinawa Trough from the sediments of Taiwan rivers, the East China Sea shelf, or the Yangtze River.

(3) Chalcopyrite, galena, pyrite, iron oxide, barite, pyrrhotite, and anhydrite are effective in distinguishing the sediment supply to the southern Okinawa Trough from shelf and fluvial sediments and the hydrothermal system.

(4) The characteristics of heavy mineral assemblages indicate that the heavy minerals in the sediments of the southern Okinawa Trough have mainly derived from Taiwan rivers and the East China Sea shelf/Yangtze River in the past 700 years. The ATi index indicates that the sediment supply of Taiwan rivers increased significantly from 1748-1792.

(5) As an effective method to identify heavy minerals, TIMA has a good application prospect in analyzing heavy mineral assemblages in marginal sea sediments. At the same time, this method, combined with manual identification, can obtain more objective and natural characteristics of heavy mineral composition.

Author Contributions: Methodology, B.Z.; software, B.Z.; validation, B.Z.; investigation, B.Z.; resources, Z.Z.; data curation, B.Z.; writing-original draft preparation, B.Z.; writing-review and editing, Z.Z.; visualization, B.Z.; supervision, Z.Z.; project administration, Z.Z.; funding acquisition, Z.Z. All authors have read and agreed to the published version of the manuscript.

Funding: This research was funded by the National Natural Science Foundation of China (Grant No. 91958213), the Special Fund for the Taishan Scholar Project of Shandong Province (Grant No. ts201511061), the National Special Fund for the 13th Five Year Plan of COMRA (Grant No. DYI35-G201-02), and the National Basic Research Program of China (Grant No. 2013CB429700).

Acknowledgments: We are grateful to Li Li from the Nanjing Hong Chuang Geological Exploration Technology Service Co. for providing detailed help on the use of software (TIMA).

Conflicts of Interest: The authors declare no conflict of interest.

\section{References}

1. Chung, Y.; Chang, W.C. Pb-210 fluxes and sedimentation rates on the lower continental slope between Taiwan and the South Okinawa Trough. Cont. Shelf Res. 1995, 15, 149-164. [CrossRef]

2. Diekmann, B.; Hofmann, J.; Henrich, R.; Fütterer, D.; Rohl, U.; Wei, K.Y. Detrital sediment supply in the southern Okinawa Trough and its relation to sea-level and Kuroshio dynamics during the late Quaternary. Mar. Geol. 2008, 255, 83-95. [CrossRef]

3. Hu, S.; Zeng, Z.; Fang, X.; Yin, X.; Chen, Z.; Li, X.; Zhu, B.; Qi, H. Increasing terrigenous sediment supply from Taiwan to the southern Okinawa Trough over the last 3000years evidenced by Sr Nd isotopes and geochemistry. Sediment. Geol. 2020, 406, 105725. [CrossRef]

4. Dou, Y.; Yang, S.; Shi, X.; Clift, P.D.; Liu, S.; Liu, J.; Li, C.; Bi, L.; Zhao, Y. Provenance weathering and erosion records in southern Okinawa Trough sediments since 28 ka: Geochemical and Sr-Nd-Pb isotopic evidences. Chem. Geol. 2016, 425, 93-109. [CrossRef]

5. Bentahila, Y.; Othman, D.B.; Luck, J.M. Strontium, lead and zinc isotopes in marine cores as tracers of sedimentary provenance: A case study around Taiwan orogen. Chem. Geol. 2008, 248, 62-82. [CrossRef]

6. Hu, S.; Zeng, Z.; Fang, X.; Zhu, B.; Chen, Z. Rare earth element geochemistry of sediments from the southern Okinawa Trough since $3 \mathrm{ka}$ : Implications for river-sea processes and sediment source. Open Geosci. 2019, 11, 929-947. [CrossRef]

7. Kao, S.J.; Lin, F.J.; Liu, K.K. Organic carbon and nitrogen contents and their isotopic compositions in surficial sediments from the East China Sea shelf and the southern Okinawa Trough. Deep Sea Res. Part II Top. Stud. Oceanogr. 2003, 50, 1203-1217. [CrossRef]

8. Li, C.; Shi, X.; Kao, S.; Chen, M.; Liu, Y.; Fang, X.; Zou, J.; Liu, S.; Qiao, S. Clay mineral composition and their sources for the fluvial sediments of Taiwanese rivers. Chin. Sci. Bull. 2012, 57, 673-681. [CrossRef]

9. Garzanti, E.; Andò, S.; Vezzoli, G. Grain-size dependence of sediment composition and environmental bias in provenance studies. Earth Planet. Sci. Lett. 2009, 277, 422-432. [CrossRef] 
10. Garzanti, E.; Andò, S. Chapter 20 Heavy Mineral Concentration in Modern Sands: Implications for Provenance Interpretation. Dev. Sedimentol. 2007, 58, 517-545.

11. Zhang, K.; Li, A.; Huang, P.; Lu, J.; Liu, X.; Zhang, J. Sedimentary responses to the cross-shelf transport of terrigenous material on the East China Sea continental shelf. Sediment. Geol. 2019, 384, 50-59. [CrossRef]

12. Lu, K.; Qin, Y.; Wang, Z.; Huang, L.; Li, G. Heavy mineral provinces of the surface sediments in central-southern East China Sea and implications for provenance. Mar. Geol. Front. 2019, 35, 20-26. (In Chinese with English Abstract)

13. Zhang, K.; Li, A.; Dong, J.; Zhang, J. Detrital Mineral Distributions in Surface Sediments of the East China Sea: Implications for Sediment Provenance and Sedimentary Environment. Acta Sedimentol. Sin. 2016, 34, 902-911, (In Chinese with English Abstract).

14. Deng, K.; Yang, S.; Wang, Z.; Li, C.; Bi, L.; Zhang, Y.; Liu, P. Detrital Heavy Mineral Assemblages in the River Sediments from Taiwan and Its Implications for Sediment Provenance. Acta Sedimentol. Sin. 2016, 34, 531-542, (In Chinese with English Abstract).

15. Chen, L. Sedimentary Mineralogy of the China Sea; Ocean Press: Beijing, China, 2008. (In Chinese)

16. Morton, A.; Hallsworth, C.; Strogen, D.; Whitham, A.; Fanning, M. Evolution of provenance in the NE Atlantic rift: The Early-Middle Jurassic succession in the Heidrun Field, Halten Terrace, offshore Mid-Norway. Mar. Pet. Geol. 2009, 26, $1100-1117$. [CrossRef]

17. Datta, D.K.; Subramanian, V. Distribution and fractionation of heavy metals in the surface sediments of the Ganges-BrahmaputraMeghna River system in the Bengal basin. Environ. Geol. 1998, 36, 93-101. [CrossRef]

18. Wang, M.; Jin, B.; Yue, W. Patterns of heavy mineral combination in different grain-size categories and their sedimentary significance: A case study for surfical sediments in the Changjiang River Estuary. Haiyang Xuebao 2019, 41, 89-100. (In Chinese with English Abstract) [CrossRef]

19. Krippner, A.; Meinhold, G.; Morton, A.C.; Russell, E.; Eynatten, H.V. Grain-size dependence of garnet composition revealed by provenance signatures of modern stream sediments from the western Hohe Tauern (Austria). Sediment. Geol. 2015, 321, 25-38. [CrossRef]

20. Yang, Y. Study on the Characteristics of Turbidite Sediments Hosted Sulfides Deposit from the Southern Okinawa Trough; University of Chinese Academy of Sciences (Institute of Oceanology, CAS): Qingdao, China, 2021.

21. Blaauw, M.; Christen, J.A. Flexible paleoclimate age-depth models using an autoregressive gamma process. Bayesian Anal. 2011, 6, 457-474. [CrossRef]

22. Feng, X. Sedimentary Characters and Genesis of Gravity Flow Deposits in the Southwestern Okinawa Trough since 1.3 ka B.P.; First Institute of Oceanology, Ministry of Natural Resources: Qingdao, China, 2020.

23. Zhang, K. Mineralogy Response to the Source and Sink Process of Modern Muddy Deposits on the East China Sea Shelf; University of Chinese Academy of Sciences (Institute of Oceanology, CAS): Qingdao, China, 2017.

24. Yang, S.; Wang, Z.; Yun, G.; Li, C.; Cai, J. Heavy mineral compositions of the Changjiang (Yangtze River) sediments and their provenance-tracing implication. J. Asian Earth Sci. 2009, 35, 56-65. [CrossRef]

25. Li, G.; Li, P.; Liu, Y.; Qiao, L.; Ma, Y.; Xu, J.; Yang, Z. Sedimentary system response to the global sea level change in the East China Seas since the last glacial maximum. Earth-Sci. Rev. 2014, 139, 390-405. [CrossRef]

26. Qin, Y. Geology of the East China Sea; Science Press: Beijing, China, 1987. (In Chinese)

27. Gena, K.; Kase, K.; Chiba, H.; Nakashima, K. Tin-bearing chalcopyrite, and platinum-bearing bismuthinite in the active Tiger sulfide chimney, Yonaguni Knoll IV seafloor hydrothermal system, Okinawa Trough, Japan. OKAYAMA Univ. Earth Sci. Rep. 2005, 12, 1-5.

28. Yang, B.J.; Liu, J.H.; Shi, X.F.; Zhang, H.; Wang, X.J.; Wu, Y.H.; Fang, X.S. Mineralogy and sulfur isotope characteristics of metalliferous sediments from the Tangyin hydrothermal field in the southern Okinawa Trough. Ore Geol. Rev. 2020, $120,103464$. [CrossRef]

29. Dill, H.G.; Siegfanz, G.; Marchig, V. Mineralogy and chemistry of metalliferous muds forming the topstratum of a massive sulfidemetalliferous sediment sequence from East Pacific rise $18^{\circ} \mathrm{S}$ : Its origin and implications concerning the formation of ochrous sediments in cyprustype deposits. Mar. Geotechnol. 1994, 12, 159-180. [CrossRef]

30. Dill, H.; Gauert, C.; Holler, G.; Marchig, V. Hydrothermal alteration and mineralisation of basalts from the spreading zone of the East Pacific Rise ( $7^{\circ} \mathrm{S}-23^{\circ}$ S). Geol. Rundsch. 1992, 81, 717-728. [CrossRef]

31. Morton, A.C.; Hallsworth, C. Identifying provenance-specific features of detrital heavy mineral assemblages in sandstones. Sediment. Geol. 1994, 90, 241-256. [CrossRef]

32. Morton, A.C.; Hallsworth, C.R. Processes controlling the composition of heavy mineral assemblages in sandstones. Sediment. Geol. 1999, 124, 3-29. [CrossRef]

33. Hubert, J.F. A Zircon-Tourmaline-Rutile Maturity Index and the Interdependence of the Composition of Heavy Mineral Assemblages with the Gross Composition and Texture of Sandstones. J. Sediment. Res. 1962, 32, 440-450.

34. Hu, S.; Zeng, Z.; Fang, X.; Qi, H.; Yin, X.; Chen, Z.; Li, X.; Zhu, B. Geochemical Study of Detrital Apatite in Sediment from the Southern Okinawa Trough: New Insights into Sediment Provenance. Minerals 2019, 9, 619. [CrossRef]

35. Thomson, S.N.; Gehrels, G.E.; Ruiz, J.; Buchwaldt, R. Routine low-damage apatite U-Pb dating using laser ablation-multicollectorICPMS. Geochem. Geophys. Geosyst. 2013, 13, Q0AA21. [CrossRef] 
36. Dunkl, I.; Eynatten, H.V.; Andò, S.; Lünsdorf, K.; Yoshida, K. Comparability of heavy mineral data-The first interlaboratory round robin test. Earth-Sci. Rev. 2020, 211, 103210. [CrossRef]

37. Xu, M.; Wei, X.; Yang, R.; Wang, P.; Cheng, X. Research progress of provenance tracing method for heavy mineral analysis. Adv. Earth Sci. 2021, 36, 154-171, (In Chinese with English Abstract). [CrossRef] 